\title{
O tempo de Laura Castilhos
}

\section{Laura Castilhos' time}

\section{Teresa Poester*}

* Artista plástica. Professora, Departamento de Artes Visuais, Instituto de Artes, Universidade Federal do Rio Grande do Sul (UFRGS), Porto Alegre, RS.

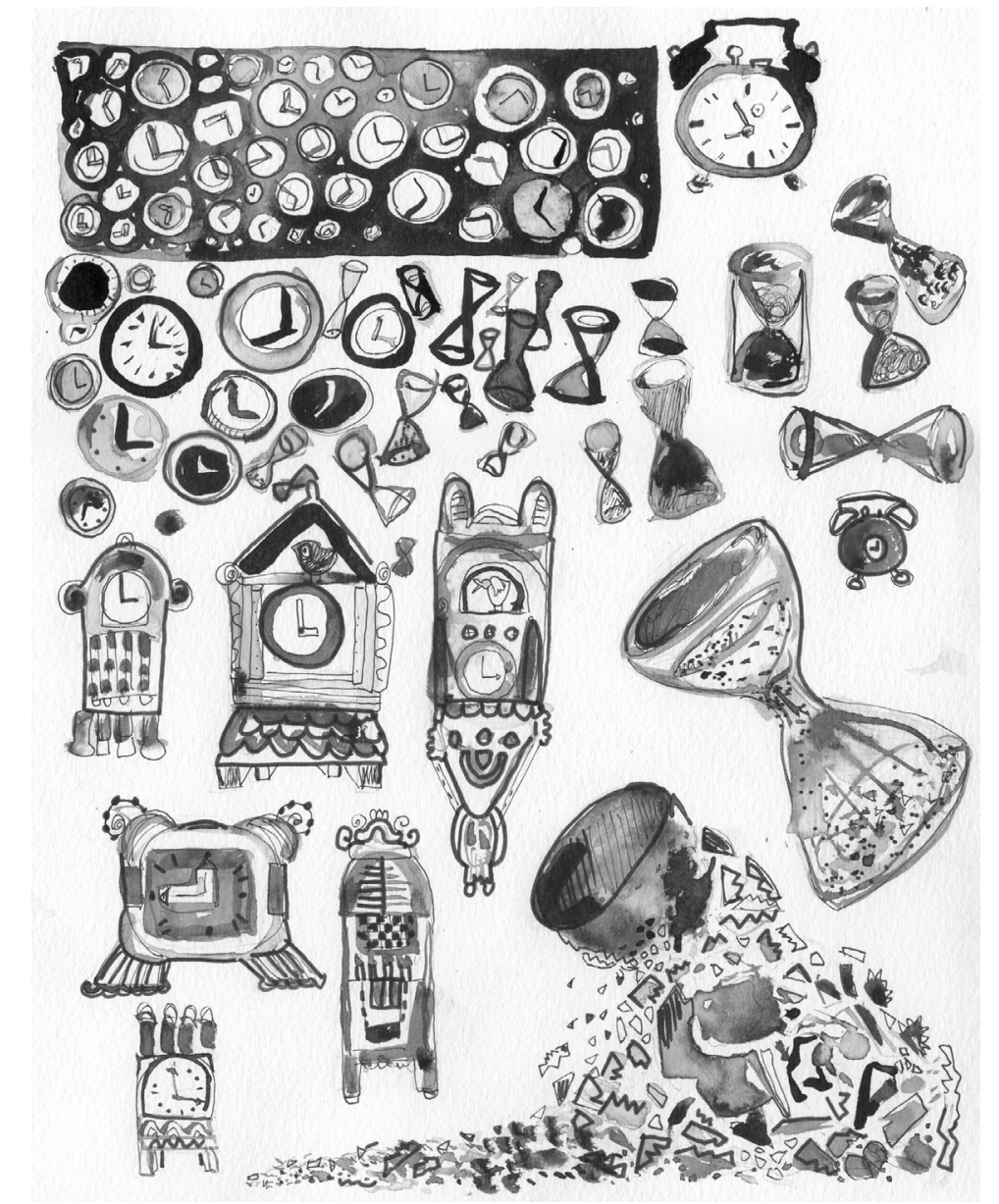

Laura Castilhos, "O tempo", nanquim e aguada sobre papel, 36 x 56 cm, 2007.

Laura Castilhos, embora com uma trajetória considerável como artista plástica, há alguns anos dedica-se mais assiduamente à ilustração. Este trabalho feito a nanquim - técnica que, assim como a aquarela, faz uma ponte entre o desenho e a pintura parece ser uma ilustração do tempo. As ampulhetas e os diferentes estilos de relógio nos mostram as várias formas de marcar um tempo que não é único, mas múltiplo. É significativo que tenha escolhido a tinta líquida para expressar esse tempo que escoa sobre o papel. Não se apaga a mancha da nanquim como a do óleo ou a da tinta acrílica. Como a aquarela, a nanquim é a técnica irreversível do ritmo da vida.

O tempo é uma abstração, uma construção humana, o que existe é o espaço e as transformações da matéria que ocupa esse espaço. Os ponteiros do 
relógio que mudam de lugar, os grãos de areia que caem graças à força da gravidade, as pinceladas do desenho que traça sua marca no papel. Desenhar é registrar imediatamente a passagem do tempo em cada ponto-instante que esvai.
E como cada coisa tem seu tempo, a chuva, o carrossel, a borboleta, o tempo de Laura Castilhos é anotado nesses desenhos/pinturas que ela tem nos presenteado ao longo dos anos, cheios de uma ternura e de um encantamento que tornam nossos instantes mais leves. 